\title{
The role of cultural engagement for older adults: an integrative review of scientific literature
}

Lilian Dias Bernardo' $\mathbb{D}$

Claudia Reinoso Araújo de Carvalho² (D)

\section{Abstract}

Objective: to understand the role of cultural engagement in the lives of older adults. Method: an integrative literature review of publications from 2014 and 2019 in English, Portuguese, and Spanish was conducted. The Scopus, Web of Science, MEDLINE/ PubMed, CINAHL, PsycNET ${ }^{\circledR}$, LILACS, SciELO Citation Index and Science Direct databases were used as sources of information. The descriptors "aged" and the related term "cultural engagement" in the three idioms were used in the search, together with the Boolean operators "AND" or " OR". A total of 12 articles that met the inclusion criteria were found. These were categorized based on the theme. No Brazilian studies were found. Results: the panorama found revealed that older adults are more interested in receptive cultural activities, such as going to museums, exhibitions and the theater, as these enrich and add greater social value to their lives. Cultural engagement was associated with a reduction in the incidence of neuropsychiatric disorders (dementia and depression), as well as reducing the incidence of episodes of violence. Participation in cultural activities also constituted a protective factor for cognitive abilities and for the reduction of chronic pain. There is also evidence that associates cultural engagement with a better perception of quality of life and greater well-being, happiness and positive affect, as well as the reduction of negative affect. Conclusion: engaging in cultural activities is a way of understanding and respecting cultural diversity, salvaging social identities, and enjoying and providing experiences of great social value, with beneficial impacts in the lives of older adults.
Keywords: Health of the Elderly. Culture.

Disease Prevention. Social Identification.

\footnotetext{
Instituto Federal de Educação Ciência e Tecnologia do Rio de Janeiro, Curso de Graduação em Terapia Ocupacional. Rio de Janeiro, RJ, Brazil.

2 Universidade Federal do Rio de Janeiro, Faculdade de Medicina, Departamento de Terapia Ocupacional. Rio de Janeiro, RJ Brazil.
}

The authors declare there are no conflicts of interest in relation to the present study.

No funding was received in relation to the present study. 


\section{INTRODUCTION}

Participation in the activities that make up our daily lives comes from individual choices, imbued with values, beliefs and experiences that, in turn, are reflections - conscious or otherwise - of the influences of a social group. Participating in these different activities is a way of expressing social identity, just as social identity influences one's engagement ${ }^{1}$.

In the choice of activities, the cultural context can be one of the aspects used to understand how people share, create and assign meanings to each activity they perform ${ }^{2}$. However, the repertoire of activities selected by people can change throughout their lives, whether by necessity, preference, ability, opportunity or by changes in their own culture ${ }^{3}$.

Several researchers have attempted to understand the involvement and participation of a social group in cultural activities by investigating the engagement and access to different facilities such as museums, theaters or monuments, as well as maintaining the cultural traditions that are passed from generation to generation ${ }^{4-7}$. However, when considering the older age group, the guiding question of such research arises: What is the nature of the engagement of older adults with cultural facilities be described? Does participation in cultural activities have any effect on the lives of these older adults? In this context, the objective of the present article was to understand the role of cultural engagement in old age.

\section{METHODS}

The present study took the form of an integrative literature review, the corpus of which was formed of scientific productions that highlight the effects of cultural engagement among older adults. The time frame adopted was five years (2014 to 2019). Searches were conducted in March 2019.

The selected information sources were: Scopus, Web of Science, MEDLINE / PubMed, Cumulative Index to Nursing and Allied Health Literature (CINAHL), PsycNET ${ }^{\circledR}$, Latin American and Caribbean Health Science Literature (LILACS), Scientific Electronic Library on Line (SciELO) Citation Index and Science Direct.

When selecting the articles the following inclusion criteria were considered, irrespective of the free access to publications: articles that addressed the theme and were in Portuguese, English or Spanish. Literature reviews, conference abstracts, annals and editorials were rejected.

In order to define the search terms, the Health Sciences Descriptors were consulted. The "older adults" descriptor and its correlates were chosen, which were combined with the search term "cultural engagement" and their respective expressions in English and Spanish. The Boolean operators "AND" and "OR" were used for combinations. The strategies constructed with the search terms and results are presented in Table 1.

A total of 139 articles were found. The works identified in the bibliographic search of the databases were exported to Microsoft Excel ${ }^{\circledR}$ spreadsheets for data storage and organization, beginning the process of selecting the research corpus. The identification, screening, eligibility and justification for exclusion steps are presented in Figure 1. In this flowchart, 12 articles met the complete selection process and comprised the final sample of this research. 
Table 1. Search strategies and results of articles identified. Rio de Janeiro, 2019.

\begin{tabular}{|l|l|l|}
\hline $\begin{array}{l}\text { Sources } \\
\text { of information }\end{array}$ & Search expressions & Results \\
\hline $\begin{array}{l}\text { CINAHL with Full Text } \\
\text { (EBSCO) }\end{array}$ & $\begin{array}{l}\text { ("aged" OR "older adults" OR "elderly" OR "older person" ) AND } \\
\text { ("cultural engagement") }\end{array}$ & 06 \\
\hline LILACS & "cultural" [Words] and "idoso" [Words] & 10 \\
\hline LILACS & "cultural" [Words] and "adultos mayores" [Words] & 00 \\
\hline LILACS & "engajamento cultural" [Words] and "idoso" [Words] & 00 \\
\hline MEDLINE/PubMed & $\begin{array}{l}\text { ("aged" OR "older adults" OR "elderly" OR "older person") AND } \\
\text { "cultural engagement" }\end{array}$ & 12 \\
\hline PsycNET & $\begin{array}{l}\text { Any Field: "aged" OR Any Field: "older adults" OR Any Field: "elderly" } \\
\text { OR Any Field: "older person" AND Any Field: "cultural engagement" }\end{array}$ & 12 \\
\hline SCIelo Citation Index & $\begin{array}{l}\text { TOPIC: ("aged" OR "older adults" OR "elderly" OR "older person") } \\
\text { AND TÓPICO: ("cultural engagement") }\end{array}$ & 00 \\
\hline Science Direct & $\begin{array}{l}\text { "aged" OR "older adults" OR "elderly" OR "older person") AND } \\
\text { TOPIC: ("cultural engagement") }\end{array}$ & 79 \\
\hline Scopus & $\begin{array}{l}\text { (TITLE-ABS-KEY ( "aged" OR "older adults" OR "elderly" OR } \\
\text { "older person" ) AND TITLE-ABS-KEY ( "cultural engagement" ) }\end{array}$ & 15 \\
\hline Web of Science & $\begin{array}{l}\text { TOPIC: ("aged" OR "older adults" OR "elderly" OR "older person") } \\
\text { AND TOPIC: ("cultural engagement") }\end{array}$ & 05 \\
\hline Total & \multicolumn{2}{|l}{} \\
\hline
\end{tabular}

Source: authors, 2019.

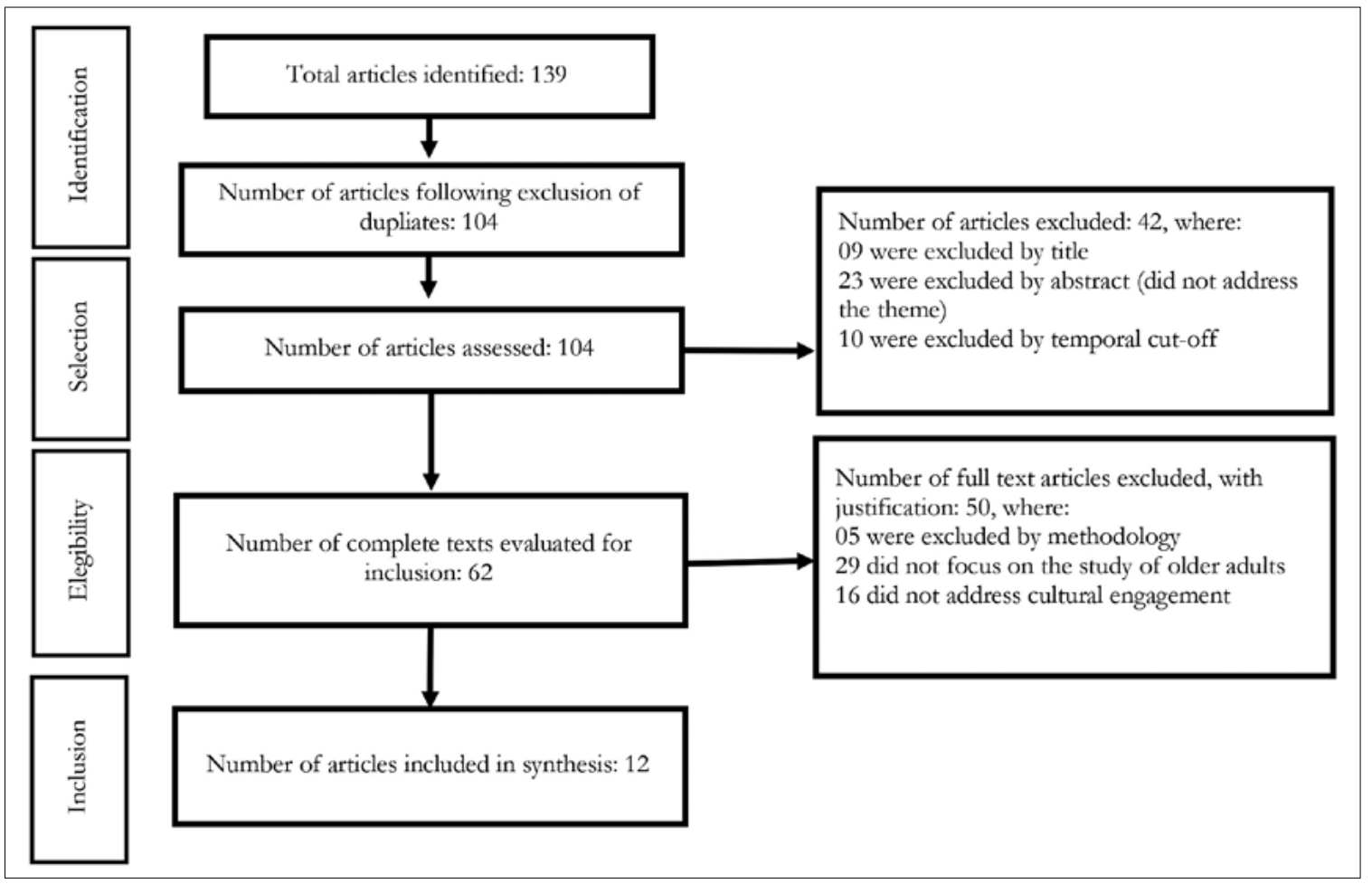

Figure 1. Selection flowchart. Rio de Janeiro, RJ, 2019.

Source: authors, 2019. 
For analysis and systematization of the obtained data, a form was created to organize the results. To select the categories of analysis, a skim reading was initially performed to familiarize the researchers with the contents of each study ${ }^{8}$. Data underwent content analysis ${ }^{8}$ for the thematic categorization process and subsequent descriptive analysis. In compliance with the theoretical framework, the articles were divided based on the objectives, methodological designs, outcomes and limitations of each study.

\section{RESULTS AND DISCUSSION}

The study is made up of 12 articles that are described in Table 2.

Table 2. Characterization of articles in relation to authors and year of publication, region in which studies took place, research objectives, methodological designs, outcomes and limitations of the studies. Rio de Janeiro, 2019.

\begin{tabular}{|c|c|c|c|c|}
\hline $\begin{array}{l}\text { Authors and } \\
\text { year. } \\
\text { (Region of } \\
\text { study) }\end{array}$ & Objectives & $\begin{array}{l}\text { Methodological } \\
\text { design }\end{array}$ & Outcomes & Limitations \\
\hline $\begin{array}{l}\text { Dyall et al. }{ }^{9}, \\
2014 . \\
\text { (New } \\
\text { Zealand) }\end{array}$ & $\begin{array}{l}\text { Relate } \\
\text { socioeconomic } \\
\text { and cultural } \\
\text { profile to } \\
\text { quality of life. }\end{array}$ & $\begin{array}{l}\text { Target population: } \\
421 \text { indigenous } \\
\text { New Zealand older } \\
\text { adults (Maori) and } \\
\text { non-Maori; } \\
\text { Age variation: } 80- \\
90 \text { years; } \\
\text { Design: } \\
\text { Transversal, cohort } \\
\text { data. }\end{array}$ & $\begin{array}{l}\text { 1) Contact with Maori culture } \\
\text { and language was related to } \\
\text { better perception of well-being. } \\
\text { 2) The frequency of visiting } \\
\text { the tribes was directly related } \\
\text { to the engagement in cultural } \\
\text { activities, with a better } \\
\text { perception of quality of life, in } \\
\text { the physical aspects. }\end{array}$ & $\begin{array}{l}\text { 1) Cross-sectional study does } \\
\text { not allow claims of causality. } \\
\text { 2) The assessment instrument } \\
\text { used applies concepts of quality } \\
\text { of life of Western society, } \\
\text { which may differ from the New } \\
\text { Zealand concept. }\end{array}$ \\
\hline $\begin{array}{l}\mathrm{Lai}^{10}, 2014 . \\
\text { (USA) }\end{array}$ & $\begin{array}{l}\text { Correlate } \\
\text { the use of } \\
\text { technologies to } \\
\text { participation in } \\
\text { socio-cultural } \\
\text { practices. }\end{array}$ & $\begin{array}{l}\text { Target population: } \\
2.250 \text { American } \\
\text { adults e older } \\
\text { adults; } \\
\text { Age variation: } 31 \text { - } \\
70 \text { years; } \\
\text { Design: } \\
\text { Transversal. }\end{array}$ & $\begin{array}{l}\text { 1) The use of the internet } \\
\text { and apps was associated with } \\
\text { engagement in socio-cultural } \\
\text { activities, with an increase in } \\
\text { the number of trips to cultural } \\
\text { facilities. }\end{array}$ & $\begin{array}{l}\text { 1) Cross-sectional study does } \\
\text { not allow claims of causality. } \\
\text { 2) There were few response } \\
\text { variables in the assessment } \\
\text { instrument and this may have } \\
\text { contributed to non-significant } \\
\text { effects. }\end{array}$ \\
\hline $\begin{array}{l}\text { Thomson e } \\
\text { Chatterjee }^{11} \text {, } \\
2014 . \\
\text { (UK) }\end{array}$ & $\begin{array}{l}\text { Correlate tactile } \\
\text { exploration in } \\
\text { works of art } \\
\text { with affect and } \\
\text { well-being. }\end{array}$ & $\begin{array}{l}\text { Target population: } \\
40 \text { British older } \\
\text { adults; } \\
\text { Age variation: 65- } \\
\text { 85; years; } \\
\text { Design: } \\
\text { Transversal. }\end{array}$ & $\begin{array}{l}\text { 1) Tactile exploration resulted } \\
\text { in increased positive affect, } \\
\text { well-being and happiness, and } \\
\text { reduced negative affect in the } \\
\text { hospital and residential settings. } \\
\text { 2) In psychiatric wards there } \\
\text { was no difference in positive } \\
\text { affect and perception of well- } \\
\text { being in the post-intervention. } \\
\text { 3) Those who had never visited } \\
\text { the museum showed a lack } \\
\text { of interest in handling the art } \\
\text { pieces and preferred to read } \\
\text { the fact sheets, demonstrating } \\
\text { curiosity. }\end{array}$ & $\begin{array}{l}\text { 1) Small sample with short term } \\
\text { interventions. } \\
\text { 2) There was no control group. } \\
\text { 4) Two interventions were used } \\
\text { (individual and group) and their } \\
\text { separate effects are not known. }\end{array}$ \\
\hline
\end{tabular}


Continuation of Chart 2

\begin{tabular}{|c|c|c|c|c|}
\hline $\begin{array}{l}\text { Ejechi }^{12} \text {, } \\
2015 . \\
\text { (Nigeria) }\end{array}$ & $\begin{array}{l}\text { Correlate } \\
\text { the level of } \\
\text { engagement in } \\
\text { socio-cultural } \\
\text { activities with } \\
\text { perception of } \\
\text { health. }\end{array}$ & $\begin{array}{l}\text { Target population: } \\
514 \text { Nigerian adults } \\
\text { and older adults; } \\
\text { Age variation: } 55- \\
75 \text { years; } \\
\text { Design: } \\
\text { Qualitative. }\end{array}$ & $\begin{array}{l}\text { 1) There was no significant } \\
\text { difference for the types of } \\
\text { socio-cultural participation } \\
\text { between retired and non-retired } \\
\text { professors. } \\
\text { 2) Participation in academic } \\
\text { activities declined significantly } \\
\text { in retired professors and } \\
\text { social participation increased, } \\
\text { especially in cultural traditions. }\end{array}$ & $\begin{array}{l}\text { 1) The sample was restricted } \\
\text { to the category of university } \\
\text { professors. Thus, it is not } \\
\text { known if the maintenance of } \\
\text { cultural traditions applies to the } \\
\text { Nigerian population. }\end{array}$ \\
\hline $\begin{array}{l}\text { Rapacciuolo } \\
\text { et al. }^{13}, 2016 . \\
\text { (Italy) }\end{array}$ & $\begin{array}{l}\text { To investigate } \\
\text { the relationship } \\
\text { between } \\
\text { subjective well- } \\
\text { being and the } \\
\text { social impact } \\
\text { and cultural } \\
\text { participation } \\
\text { of residents of } \\
\text { an Italian city } \\
\text { in a time of } \\
\text { economic crisis. }\end{array}$ & $\begin{array}{l}\text { Target population: } \\
571 \text { Italian older } \\
\text { adults; } \\
\text { Age variation: 62- } \\
77 \text { years; } \\
\text { Design: } \\
\text { Transversal. }\end{array}$ & $\begin{array}{l}\text { 1) There is an association } \\
\text { between participation in socio- } \\
\text { cultural activities and subjective } \\
\text { well-being and resilience. } \\
\text { 2) Many were unemployed and } \\
\text { the city was in economic crisis. } \\
\text { As women did not participate } \\
\text { in social and cultural activities, } \\
\text { they had lower well-being and } \\
\text { were less resilient, as availability } \\
\text { and access to cultural and social } \\
\text { activities was a key element for } \\
\text { a healthy environment. } \\
\text { 3) Women scored higher than } \\
\text { men in happiness when life } \\
\text { satisfaction was assessed. }\end{array}$ & $\begin{array}{l}\text { 1) Although not described by } \\
\text { the authors, one limitation } \\
\text { is due to the study design. } \\
\text { Longitudinal studies are } \\
\text { best suited to investigating } \\
\text { emotional aspects and their } \\
\text { relationships with cultural } \\
\text { access and participation. } \\
\text { 2) the socioeconomic condition } \\
\text { variable was not highlighted, } \\
\text { since this was the reason for } \\
\text { the restricted participation of } \\
\text { women in cultural devices. }\end{array}$ \\
\hline $\begin{array}{l}\text { Annear et } \\
\text { al. }^{14}, 2016 . \\
\text { (Australia) }\end{array}$ & $\begin{array}{l}\text { Identify the } \\
\text { practices } \\
\text { adopted } \\
\text { in nursing } \\
\text { homes to keep } \\
\text { older people } \\
\text { connected to } \\
\text { their cultures. }\end{array}$ & $\begin{array}{l}\text { Target population: } \\
3 \text { institutions with } \\
\text { Japanese older } \\
\text { adults; } \\
\text { Age variation: not } \\
\text { applicable; } \\
\text { Design: } \\
\text { Descriptive. }\end{array}$ & $\begin{array}{l}\text { 1) To foster cultural } \\
\text { engagement, long-term care } \\
\text { facilities for older adults } \\
\text { carried out activities preserving } \\
\text { Japanese traditions (flowers, } \\
\text { food and dancing) to keep such } \\
\text { adults connected to culture. }\end{array}$ & $\begin{array}{l}\text { 1) The authors did not describe } \\
\text { the limitations, but the data } \\
\text { collection did not include the } \\
\text { perception of the older adults } \\
\text { about the strategies to connect } \\
\text { them to cultural traditions. }\end{array}$ \\
\hline $\begin{array}{l}\text { Shepherd et } \\
\text { al. }{ }^{4}, 2018 . \\
\text { (Australia) }\end{array}$ & $\begin{array}{l}\text { Relate identity } \\
\text { and cultural } \\
\text { engagement } \\
\text { to recurrence } \\
\text { of violence in } \\
\text { indigenous } \\
\text { people in } \\
\text { custody. }\end{array}$ & $\begin{array}{l}\text { Target population: } \\
119 \text { Australian } \\
\text { indigenous adults } \\
\text { and older adults; } \\
\text { Age variation: 19- } \\
63 \text { years; } \\
\text { Design: } \\
\text { Longitudinal. }\end{array}$ & $\begin{array}{l}\text { 1) The level of cultural } \\
\text { engagement was greater in } \\
\text { those who had a stronger } \\
\text { cultural identity. } \\
\text { 2) There is a negative } \\
\text { relationship between cultural } \\
\text { engagement and the recurrence } \\
\text { of violence, explained by } \\
\text { increased self-esteem, self- } \\
\text { confidence, social support and } \\
\text { purpose in life. }\end{array}$ & $\begin{array}{l}\text { 1) Although the participants } \\
\text { were indigenous, they were } \\
\text { from different regions and } \\
\text { their cultural values could vary } \\
\text { wildly. } \\
\text { 2) It is not known if the natives } \\
\text { harbored multiple identities, } \\
\text { without noting their preference } \\
\text { of indigenous identity. . }\end{array}$ \\
\hline
\end{tabular}


Continuation of Chart 2

\begin{tabular}{|c|c|c|c|c|}
\hline $\begin{array}{l}\text { Fancourt et } \\
\mathrm{al}^{15}, 2018 . \\
(\mathrm{UK})\end{array}$ & $\begin{array}{l}\text { Relate cultural } \\
\text { engagement } \\
\text { to risk of } \\
\text { developing } \\
\text { dementia. }\end{array}$ & $\begin{array}{l}\text { Target population: } \\
3.911 \text { British adults } \\
\text { and older adults; } \\
\text { Age variation: } 56- \\
72 \text { years; } \\
\text { Design: Cohort. }\end{array}$ & $\begin{array}{l}\text { 1) Those who visited museums } \\
\text { a few times a month or more } \\
\text { had a lower incidence of } \\
\text { dementia, regardless of the } \\
\text { variables: sensory impairment, } \\
\text { depression and vascular } \\
\text { conditions. } \\
\text { 2) The cognitive stimulation } \\
\text { provided by museum visits } \\
\text { makes cultural engagement } \\
\text { an important strategy for } \\
\text { maintaining cognitive reserve } \\
\text { and reducing social isolation. }\end{array}$ & $\begin{array}{l}\text { 1) The study was not } \\
\text { experimental. }\end{array}$ \\
\hline $\begin{array}{l}\text { Goulding }^{16} \text {, } \\
2018 . \\
\text { (UK) }\end{array}$ & $\begin{array}{l}\text { Correlate } \\
\text { the degree } \\
\text { of cultural } \\
\text { involvement } \\
\text { and its effects } \\
\text { on the lives of } \\
\text { older adults. }\end{array}$ & $\begin{array}{l}\text { Target population: } \\
40 \text { British older } \\
\text { adults; } \\
\text { Age variation: } 64- \\
98 \text { years; } \\
\text { Design: qualitative. }\end{array}$ & $\begin{array}{l}\text { 1) Participants engaged in } \\
\text { cultural activities to enrich } \\
\text { themselves socially. } \\
\text { 2) For those with lower levels of } \\
\text { education and from lower social } \\
\text { classes, cultural engagement } \\
\text { was more restricted. }\end{array}$ & $\begin{array}{l}\text { 1) Groups varied greatly in size } \\
\text { and opportunities for cultural } \\
\text { engagement . } \\
\text { 3) Not all older people were } \\
\text { retired, which reflected in lower } \\
\text { cultural participation and may } \\
\text { have influenced outcomes. }\end{array}$ \\
\hline $\begin{array}{l}\text { Fancourt } \\
\text { and } \\
\text { Steptoe }^{6} \text {, } \\
2018 \text { (a). } \\
\text { (UK) }\end{array}$ & $\begin{array}{l}\text { Correlate } \\
\text { cultural } \\
\text { engagement } \\
\text { with cognitive } \\
\text { skills. }\end{array}$ & $\begin{array}{l}\text { Target population: } \\
3.445 \text { British adults } \\
\text { and older adults; } \\
\text { Age variation: } 52- \\
90 \text { years; } \\
\text { Design: } \\
\text { Transversal, cohort } \\
\text { data. }\end{array}$ & $\begin{array}{l}\text { 1) Cultural engagement } \\
\text { seems to have benefits for } \\
\text { memory and semantic fluency, } \\
\text { regardless of cognitive status, } \\
\text { demographic variables, } \\
\text { perception of health, and } \\
\text { participation in activities. } \\
\text { 2) The higher the frequency } \\
\text { of engagement, the greater the } \\
\text { protective factor for cognition, } \\
\text { except for going to the movies. } \\
\text { 3) There was no correlation } \\
\text { between going to the theater/ } \\
\text { concerts/opera and semantic } \\
\text { fluency. }\end{array}$ & $\begin{array}{l}\text { 1) Cross-sectional study does } \\
\text { not allow claims of causality. } \\
\text { 2) Data were collected from } \\
\text { the previous year only, with } \\
\text { no longer deadlines, which } \\
\text { does not allow us to draw } \\
\text { conclusions on the perpetuation } \\
\text { of benefits. } \\
\text { 3) There may be a two-way } \\
\text { relationship between culture, } \\
\text { engagement and cognition. }\end{array}$ \\
\hline $\begin{array}{l}\text { Fancourt } \\
\text { and Steptoe }{ }^{7} \text {, } \\
2018(\mathrm{~b}) . \\
(\mathrm{UK})\end{array}$ & $\begin{array}{l}\text { Correlate } \\
\text { physical and } \\
\text { psychosocial } \\
\text { factors (culture) } \\
\text { with chronic } \\
\text { pain. }\end{array}$ & $\begin{array}{l}\text { Target population: } \\
2.631 \text { British adults } \\
\text { and older adults; } \\
\text { Age variation: } 52- \\
90 \text { years; } \\
\text { Design: } \\
\text { Transversal, cohort } \\
\text { data. }\end{array}$ & $\begin{array}{l}\text { 1) Cultural engagement appears } \\
\text { as a psychosocial factor that } \\
\text { protects chronic pain, except } \\
\text { for participation activities in } \\
\text { community groups. } \\
\text { 3) Cultural engagement proved } \\
\text { benefits regardless of sedentary } \\
\text { behavior, physical activity and } \\
\text { social isolation. }\end{array}$ & $\begin{array}{l}\text { 1) Cross-sectional study does } \\
\text { not allow claims of causality. } \\
\text { 2) This sample is representative } \\
\text { of white British people, but the } \\
\text { results for other ethnicities are } \\
\text { not known. }\end{array}$ \\
\hline $\begin{array}{l}\text { Fancourt } \\
\text { and } \\
\text { Tymoszuk } \\
2019 . \\
\text { (UK) }\end{array}$ & $\begin{array}{l}\text { Relate cultural } \\
\text { engagement to } \\
\text { the incidence of } \\
\text { depression. }\end{array}$ & $\begin{array}{l}\text { Target population: } \\
2.148 \text { British adults } \\
\text { and older adults; } \\
\text { Age variation: } 52- \\
89 \text { years; } \\
\text { Design: Cohort. }\end{array}$ & $\begin{array}{l}\text { 1) The higher the frequency of } \\
\text { cultural activities, the lower the } \\
\text { risk of developing depression, } \\
\text { regardless of sociodemographic, } \\
\text { health, behavior and forms of } \\
\text { social engagement (hobbies, } \\
\text { social interactions, community } \\
\text { group) and civic variables. }\end{array}$ & $\begin{array}{l}\text { 1) Cross-sectional study does } \\
\text { not allow claims of causality. } \\
\text { 2) May have participants } \\
\text { with subclinical moods or } \\
\text { depression that would explain } \\
\text { the reduction in engagement. }\end{array}$ \\
\hline
\end{tabular}

Source: Created by authors from data obtained in study, 2019. 
When characterizing the research corpus, there was an absence of studies that considered the Brazilian or the Latin American population. Most of the productions were recent $(2018, n=5)$ and from the UK ( $\mathrm{n}=6)$. All the studies considered were published in English.
To analyze the relationship of the keywords used in the publications reviewed, an infographic was constructed to understand the terms and their associations (figure 2).

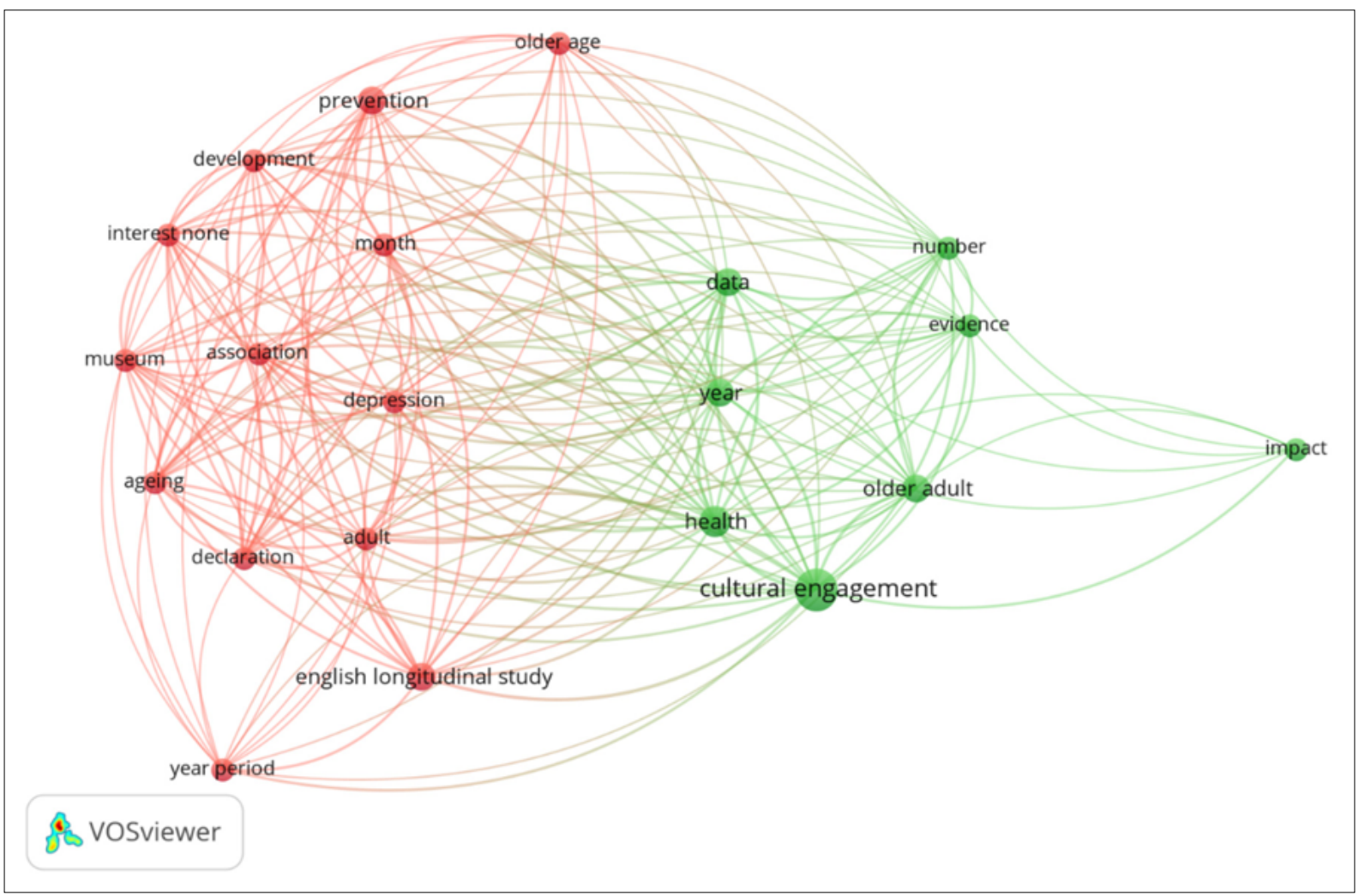

Figure 2. Infographic of terms used in articles.

Source: authors' own production, 2019.

In this representation, the size of the circle is directly proportional to the frequency and importance of the analyzed items. Circles are grouped by subject and represented by different colors ${ }^{17}$. Thus, clusters are observed, in which the following keywords stand out: cultural engagement, older adults, aging and older age, health and prevention. The connections demonstrated that research has been carried out to establish the relationship between culture and health promotion/disease prevention.

In the analysis of the objectives and methodological designs, it was found that the publications were conducted exclusively with an older population $(n=5)$ or groups of adults and older adults $(n=7)$. In this case, five studies included people older than 45 years ${ }^{5-7,12,15}$ and two considered younger people ${ }^{4,10}$. In articles with adult and older adult participants, age did not interfere with the results achieved.

Regarding the goals of the studies, the authors were concerned with investigating which cultural facilities the older adults chose $e^{6,10}$, assessing the perceptions of individuals when participating in cultural activities $9,11-14,16$, and evaluating the relationship between cultural engagement and body functions $s^{5-7,15}$ or changes.

In the analysis of the objectives and outcomes, it appears that the studies by Lai ${ }^{10}$ and Goulding ${ }^{16}$ attempted to understand which were the most sought after cultural facilities among older adults. 
For people who made frequent use of the internet or apps, museums and art galleries were the most sought after places, followed by music festivals, historical sites, parks or monuments ${ }^{10}$. The author suggests that technology is a supportive resource for cultural engagement, as it stimulates greater interest in visiting existing places and provides an increase in sociocultural experiences ${ }^{10}$. In the study by Goulding $^{16}$, participation in art history and literature classes, choirs, reading groups and museum visits appeared in this order as the choices of older adults to add greater social value to their experiences at this stage of life.

In the other studies in which cultural facilities were the effective spaces for achieving the objectives of each study, the museum was the most common location.

Some studies sought to understand the perception of cultural engagement in the lives of older adults, namely those by Dyall et al. ${ }^{9}$, Thomson and Chatterjee $^{11}$, Ejechi ${ }^{12}$, Rapacciuolo et al. ${ }^{13}$, Annear et al. $^{14}$ and Goulding ${ }^{16}$.

In the studies by Dyall et al. ${ }^{9}$, Ejechi $^{12}$ and Annear et al. ${ }^{14}$, the perceptions of older adults about maintaining their cultural traditions were investigated. The greater frequency of contact between indigenous peoples (city-dwelling) and their tribes and native languages was associated with a better perception of quality of life and well-being?

In the study by Ejechi ${ }^{12}$ meanwhile, Nigerian professors reported that they remained engaged in their cultural traditions, such as performing funeral or marriage rites, attending naming ceremonies, and worshiping the gods, represented a successful aging.

Maintaining the Japanese culture and tradition was also the strategy adopted by three long-term institutions for older adults, with the intention of offering potential gains in quality of life and health for institutionalized older adults ${ }^{14}$. The use of traditional Japanese flowers, festivals and foods were the strategies used to connect older adult residents with the outside world and their inherited culture ${ }^{14}$.

Among the other studies that sought to understand the relationship between culture and the perceptions of the research participants, that by Rappaciuolo et al. ${ }^{13}$ investigated the cultural participation of residents of a city in economic crisis: Naples. In the survey year (2014), the unemployment figures were increasing and the opportunities for socio-cultural experiences were in decline. It was found that men had greater opportunities for cultural and social participation and had a better perception of well-being and resilience compared to women in the survey ${ }^{13}$.

In turn, tactile experiences with museum collections was the strategy adopted to provide cultural experiences in older adults who - due to health or age - were restricted in their attendance of cultural establishments ${ }^{11}$. Tactile exploration was associated with increased positive affect, well-being and happiness, and decreased negative affect. There was no difference before and after the intervention for positive affect and well-being in the psychiatric ward participants $^{11}$. Those with no previous experience of museum visits showed curiosity about the collection, but restricted themselves to reading the fact sheets without becoming involved in tactile exploration ${ }^{11}$.

By analyzing the relationship between cultural engagement and bodily diseases/functions, scientific studies have shown that participation in cultural activities is associated with lower decline in cognitive functions $^{6}$, chronic pain ${ }^{7}$, incidence of dementia ${ }^{15}$ and depression ${ }^{5}$, as well as a lower recurrence of episodes of violence ${ }^{4}$. These studies stated that the frequency of engagement was directly related to increased benefits ${ }^{4-7,15}$.

In the study by Fancourt and Steptoe ${ }^{6}$ there was a direct relationship between the number of trips to museums, art galleries and/or shows and lower cognitive decline, especially in memory functions and semantic fluency. However, the practice of going to the movies showed no association between frequency and protection of cognition. Similarly, going to concert or the theater/opera had no positive relationship with semantic fluency, which may be due to the late development of interest in these cultural modalities.

Maintaining cognitive skills during museum visits was also associated with a lower incidence rate of dementia, reported in a cohort study over ten years $^{15}$. This study also reinforces the finding that cultural engagement was associated with lesser social 
isolation. Similarly, the social interactions provided by engaging in going to the movies, museums, galleries or the theater and watching concerts/opera was also a variable that reduced the incidence rate of depression. ${ }^{5}$.

The engagement in these cultural opportunities, similarly, emerged as a protective factor for reports of chronic pain? The authors believe that the reduction of pain, by approximately $25 \%$, was due to cultural activities promoting responses of positive affect and social interaction, as well as being a low resistance physical activity?

In turn, the study of indigenous people in custody dealt with the issues of their culture and tribal past. In those with a strong cultural identity, there were behavioral changes within the penitentiary, represented by reduced episodes of violence ${ }^{4}$.

In analyzing the limitations of the reviewed studies, the methodological designs were the most frequent limiting factor.

\section{DISCUSSION}

The present integrative review of literature reveals, in the small number of scientific productions found, that the theme remains little explored. Although the area has been growing over the years, most studies came from the same region (UK) and the same group of researchers. Restricting research to one territory may not reflect the real role of cultural engagement in old age, as different populations, ethnic variations, opportunities, and availability of resources in each region and their cultures are not considered ${ }^{3}$.

Although cultural participation is beneficial to the lives of older adults, collecting cross-sectional data (most methodological designs) does not allow causality to be established, as this method is limited to reporting a panorama ("snapshot") of the object under study, identifying the factors related to the research problem. As they lack a sequential (temporal) follow-up on the studied phenomenon, they are subject to bias by extrinsic factors ${ }^{18}$. However, these cross-sectional research designs contribute to the elaboration of experimental studies that can control the variables capable of interfering in the outcomes and thus monitor the results longitudinally, or propose a follow-up analysis, to identify whether the benefits presented are perpetuated.

The reviewed studies indicate that, despite the diversity of cultural facilities frequented and traditions identified in this review, the museum was the most sought after space by older adults, or the place most used for the data collection in investigations. This is because museums are institutions that are traditionally used to document, preserve and exhibit cultural, material or immaterial heritage ${ }^{19}$. However, the articles indicate other useful facilities for future research on cultural dissemination and experiences, such as libraries, theaters, cinemas and monuments.

Overall, the researchers were interested in investigating the relationship between participation in cultural activities and improvements in health and well-being ${ }^{20-23}$. In line with the reviewed articles, maintaining inherited cultural traditions between generations provided experiences of positive affect, better social coexistence and the strengthening of interpersonal ties ${ }^{12}$.

Similarly, participation in different cultural opportunities increased self-esteem and positive emotions, as well as reducing social isolation, anxiety and agitation ${ }^{21}$ and enabled the building of resilience ${ }^{24}$. Because of these benefits, researchers highlighted the importance of developing cultural heritage studies for the creation of health programs, as well as the elaboration of public policies. ${ }^{21,23}$.

On the other hand, considering institutionalized older adults, studies highlight that within this care modality there are reports of greater social isolation, loss of identity and reduction of affective bonds ${ }^{25,26}$. Thus, the studies presented here, conducted in longterm care facilities, seem to be concerned with the health and quality of life of their residents while maintaining cultural traditions.

In addition, research corroborates the findings of this integrative review by reaffirming the benefits of cultural participation for body functioning. There are positive relationships between cultural engagement and protection against cognitive decline 
by maintaining mental functions for a longer period ${ }^{27}$. However, in older adults with dementia, museum experiences had no benefit on cognitive functions, although their effects were positive for mood regulation and the promotion of social interactions ${ }^{28}$.

In addition, a reduction in the rate of depression was also found in older adults who performed the tactile exploration of museum collections ${ }^{29}$, as well as in adults and older adults who participated in concerts, theaters and cinemas ${ }^{30}$ and in research that investigated older adults who took part in a community choir ${ }^{31}$.

The literature also points to the benefits of culture in behavior and the perception of pain. The strong cultural identity with other indigenous prisoners associated violence with the poor perception of social and emotional well-being which, in turn, had associations with cultural, spiritual, physical and/ or social aspects ${ }^{32,33}$. Similarly, researchers reaffirm the inverse relationship between sociocultural engagement and pain, in which positive affect was considered a "painkiller" in the lives of people with chronic pain ${ }^{34,35}$.

In the present integrative review, certain themes related to the universal right to participate in cultural experiences were not discussed, but may serve as recommendations for future research. No articles were found that sought to identify the environmental and social barriers imposed on these older adults while participating in cultural activities. In addition, older adults with physical, mental and/ or sensory disabilities did not participate in the studies. Inclusion policies for people with disabilities and specifically policies for inclusion in culture - are regulated by law as part of the full exercise of citizenship ${ }^{36,37}$. However, studies suggest that people with disabilities still experience difficulties in accessing and participating in cultural services and facilities, due to the lack of accessibility, whether architectural and/or attitudinal ${ }^{38}$. The debate on cultural accessibility for the population with specific needs is necessary to broaden access and participation in cultural activities for all.
In a complementary manner, debates regarding socioeconomic conditions ${ }^{38}$ and/or educational experience $^{16}$ and their relationships with cultural access and engagement should also be better discussed in future scientific productions. Offering opportunities for cultural participation to older people - with different incomes and educational levels - respectfully, without physical, communication, information and attitude barriers, is a way of making a commitment to the democratization of culture ${ }^{39}$. In addition, studies on strategies to disseminate cultural rights contribute to a better awareness of the social rights of older adults.

\section{CONCLUSION}

Engaging in cultural activities is a way of understanding and respecting cultural diversity, rescuing social identities, enjoying and providing experiences of high social value, with beneficial impacts on the lives of older people.

In the present integrative review, it was found that older adults were more interested in receptive cultural activities (museums, galleries, and theater). Cultural engagement was associated with the protection of cognitive skills or the reduced incidence of neuropsychiatric diseases, chronic pain and inappropriate behavior. Similarly, culture was associated with a better perception of quality of life, well-being, happiness and positive affect.

When considering the issues of aging in the public policy agenda, it has been found that this theme is still related to dependence, inactivity, frailty and disease, aspects that are also the most recurrent in studies and research in the area. Thus, the present study - in line with conferences around the world, which have reinforced the need to expand research in gerontology - sought to contribute through a different approach, targeting the diverse needs of older people. Review studies such as this one constitute an initial phase of identifying demands and gaps in a given theme, and from them new research possibilities emerge.

Edited by: Tamires Carneiro Oliveira Mendes 


\section{REFERENCES}

1. Polatajko HL, Molke D, Baptiste S, Doble S, Santha JC, Kirsh B, et al. Occupational science: imperatives for occupational therapy. In: Townsend EA, Polatajko HL. Enabling occupation II: advancing an Occupational Therapy vision for health, well-being, and justice through occupation. 2th ed. Toronto: CAOT; 2013. p. 63-82.

2. Padilla R. Cultural diversity of aging population. In: Padilla R, Byers-Connon S, Lohman HL. Occupational Therapy with elders: strategies for de COTA. $3^{\text {a }}$ ed. Atlanta: Elsevier; 2012. p.121-34.

3. Meriano C, Latella D. Introduction. In: Meriano C, Latella D. Occupational Therapy Interventions: functions and occupations. Thorofare: SLACK Incorporated; 2007. p.1-34.

4. Shepherd SM, Delgado RH, Sherwood J, Paradie $\mathrm{Y}$. The impact of indigenous cultural identity and cultural engagement on violent offending. BMC Public Health. 2018;18(1):50-7.

5. Fancourt D, Tymoszuk U. Cultural engagement and incident depression in older adults: evidence from the English Longitudinal Study of Ageing. Br J Psychiatr. 2019;214(4):225-9.

6. Fancourt D, Steptoe A. Physical and psychosocial factors in the prevention of chronic pain in older age. J Pain. 2018;18(1):1385-91.

7. Fancourt D, Steptoe A. Cultural engagement predicts changes in cognitive function in older adults over a 10 year period: findings from the English Longitudinal Study of Ageing. Nature. 2018;8(1):10226-34.

8. Bardin L. Análise de conteúdo. São Paulo: Edições 70; 2011.

9. Dyall L, Kepa M, The R, Mules R, Moyes SA, Wham $\mathrm{C}$, et al. Cultural and social factors and quality of life of Maori in advanced age. Te puawaitanga o nga tapuwae kia ora tonu - Life and living in advanced age: a cohort study in New Zealand (LiLACS NZ). N Z Med J. 2014;127(1393):62-79.

10. Lai CH. An integrated approach to untangling mediated connectedness with online and mobile media. Comput Human Behav. 2014;31(1):20-6.

11. Thomson LJM, Chatterjee HJ. Well-being with objects: evaluating a museum object-handling intervention for older adults in health care settings. J Appl Gerontol. 2014;24(1):1-14.

12. Ejechi EO. Social activities of retired Nigerian academics: the applicability of the continuity theory. Act Adapt Aging. 2015;39(1):64-76.
13. Rapacciuolo A, Filardi PP, Cuomo R, Mauriello V, Quarto M, Kisslinger A, et al. The impact of social and cultural engagement and dieting on well-being and resilience in a group of residents in the metropolitan area of Naples. J Aging Res. 2016;1(1):1-11.

14. Annear MJ, Otani J, Sun J. Experiences of Japanese aged care: the pursuit of optimal health and cultural engagement. Age Ageing. 2016;45(6):753-6.

15. Fancourt D, Steptoe A, Cadar D. Cultural engagement and cognitive reserve: museum attendance and dementia incidence over a 10-year period. Br J Psychiatr. 2018;213(5):661-3.

16. Goulding A. The role of cultural engagement in older people's lives. Cult Sociol. 2018;12(4):518-39.

17. Eck NJV, Waltman L. VOSviewer Manual. Amsterdam: Universiteit Leiden; 2013.

18. Hochman B, Nahas FX, Oliveira Filho RS, Ferreira LM. Desenhos de pesquisa. Acta Cir Bras. 2005;20(2):2-9.

19. International Council of Museums Brasil. Museus [Internet]. [acesso em 20 maio 2019]. São Paulo: ICOM; 2018. Disponível em: http://www.icom.org.br/?p=1750

20. Renton A. Think of your art-eries: Arts participation, behavioural, cardiovascular risk factors and mental well-being in deprived communities in London. Public Health. 2012;126(1):57-64.

21. Chatterjee HJ, Camic PM. The health and well-being potential of museums and art galleries. Arts Health. 2015;7(3):183-6.

22. Weziak-Białowolska D. Attendance of cultural events and involvement with the arts impact evaluation on health and well-being from a Swiss household panel survey. Public Health. 2016;139:161-9.

23. Camic PM, Chatterjee HJ. Museums and art galleries as partners for public health interventions. Perspect Public Health. 2013;133(1):66-71.

24. Gordon-Nesbitt R, Howarth A. The arts and the social determinants of health: findings from an inquiry conducted by the United Kingdom all-party parliamentary group on arts, health and wellbeing. Arts Health. 2019;24:1-22.

25. Camacho ACLF, Abreu LTA, Leite BS, Mata ACO, Marinho TF, Valente GSC. Revisão integrativa sobre cuidados de enfermagem à pessoa com doença de Alzheimer e seus cuidadores. J Res Fundamental Care. 2013;5(3):186-93. 
26. Struckmeyer LR, Pickens ND. Home modifications for people with Alzheimer's disease: a scoping review. Am J Occup Ther. 2016;70(1):7001270020 [9 p.].

27. Graves AB, Rajaram L, Bowen JD, McCormick WC, McCurry SM, Larson EB. Cognitive decline and Japanese culture in a cohort of older Japanese Americans in King County, WA: the Kame Project. J Gerontol Ser B Psychol Sci Soc Sci. 1999;54(3):154-61.

28. Belver MH, Ullán AM, Avila N, Moreno C, Hernández C. Art museums as a source of well-being for people with dementia: an experience in the Prado Museum. Arts Health. 2018;10(3):213-26.

29. Solway R, Thompson L, Camic PM, Chatterjee HJ. Museum object handling groups in older adult mental health inpatient care. Int J Ment Health Promot. 2015;17(4):201-14.

30. Cuypers K, Krokstad S, Holmen TL, Skjei Knudtsen M, Bygren LO, Holmen J. Patterns of receptive and creative cultural activities and their association with perceived health, anxiety, depression and satisfaction with life among adults: the HUNT study, Norway. J Epidemiol Community Health. 2011;66(8):698-703.

31. Coulton S, Clift S, Skingley A, Rodriguez J. Effectiveness and cost-effectiveness of community singing on mental health-related quality of life of older people: randomised controlled trial. $\mathrm{Br} \mathrm{J}$ Psychiatr. 2015;207(3):250-5.

32. Trofimovs J, Dowse L. Mental health at the intersections: the impact of complex needs on police contact and custody for Indigenous Australian men. Int. J. Law Psychiatry. 2014;37(1):390-8.
33. Shepherd SM, Ogloff JRP, Shea D, Pfeifer JE, Paradies Y. Aboriginal prisoners and cognitive impairment: the impact of dual disadvantage on Social and Emotional Wellbeing. J Intellect Disabil Res. 2017;61(4):385-97.

34. Owaria Y, Miyatake N. Relationship between chronic low back pain, social participation, and psychological distress in elderly people: a pilot mediation analysis. Acta Med Okayama. 2018;72(4):337-42.

35. Finan PH, Garland EL. The role of positive affect in pain and its treatment. Clin J Pain. 2015;31(2):177-87.

36. Brasil. Lei no 10.098, de 19 de dezembro de 2000. Estabelece normas gerais e critérios básicos para a promoção da acessibilidade das pessoas portadoras de deficiência ou com mobilidade reduzida, e dá outras providências. Diário Oficial da União [Internet]. 2000. Disponível: http://www.planalto. gov.br/ccivil_03/LEIS/L10098.htm

37. Brasil. Decreto n 9.522, de 08 de outubro de 2018. Promulga o Tratado de Marraqueche para facilitar o acesso a obras publicadas às pessoas cegas, com deficiência visual ou com outras dificuldades para ter acesso ao texto impresso, firmado em Marraqueche, em 27 de junho de 2013. Diário Oficial da União [Internet]. 2018. Disponível em: http://www.planalto.gov.br/ ccivil_03/_Ato2015-2018/2018/Decreto/D9522.htm

38. Dorneles PS, Carvalho CRA, Silva ACC, Mefano V. Do direito cultural das pessoas com deficiência. Rev Polit Públicas. 2018;22(1):139-56.

39. Molenzani AO, Rocha JN. Acessibilidade nos museus e centros de ciências da cidade de São Paulo. Rev EDICC. 2017;3(3):3-14. 